\title{
The effects of focal brain damage on fracture healing: An experimental rat study
}

\author{
Fokal beyin hasarının kıık iyileşmesine etkileri: Deneysel bir sıçan çalışması
}

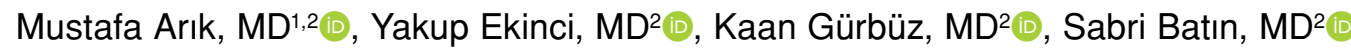 \\ 1Department of Orthopedics and Traumatology, Başkent University Medical Faculty, Ankara, Turkey \\ ${ }^{2}$ Department of Orthopedics and Traumatology, Kayseri City Hospital, Kayseri, Turkey
}

\begin{abstract}
Objectives: This study aims to investigate whether the motor cortex (MC) or the somatosensory cortex (SC) is more active during the course of bone healing after traumatic brain injury (TBI).

Materials and methods: Thirty-three male Wistar albino rats (age, 8 to 10 months; weighing, 250 to $300 \mathrm{~g}$ ) were randomized into three groups as the control group, MC damage group and SC damage group. Two rats from each brain damage group were sacrificed to verify the locations of the cortical injuries. Callus formation, callus/diaphysis ratios, and serum alkaline phosphatase (ALP) levels were measured at one, three and six weeks.
\end{abstract}

Results: The increases in callus masses in the control, $\mathrm{MC}$, and SC groups were statistically significantly different between one and three weeks $(\mathrm{p}<0.05)$. Although this increase in the MC and SC groups was significant compared to the control group at the end of one week, no statistically significant difference was found between the MC and SC groups $(\mathrm{p}>0.05)$. There was a statistically significant difference in callus/diaphysis ratio between control, MC and SC groups in favor of MC group only at one week $(\mathrm{p}<0.05)$. The increase in serum ALP levels at three weeks was statistically significantly different in the MC and SC groups compared to the control group and significantly higher in the $\mathrm{MC}$ group compared to the SC group $(\mathrm{p}<0.05)$.

Conclusion: There is a possible relationship between enhanced fracture healing after TBI and damage in the MC. Motor cortex plays a more active role on fracture healing in TBI.

Keywords: Bone healing, motor cortex, somatosensory cortex, traumatic brain injury.

\section{ÖZ}

Amaç: $\mathrm{Bu}$ çalışmada travmatik beyin yaralanması (TBY) sonrası kırık iyileşmesi süresince motor korteks (MK)'in mi yoksa somatosensöriyel korteks (SK)'in mi daha aktif olduğu araştırıldı.

Gereç ve yöntemler: Otuz üç erkek Wistar albino sıçan (yaş, 8-10 ay; ağırlık, 250-300 g) kontrol grubu, MK hasar grubu ve SK hasar grubu olarak üç gruba randomize edildi. Kortikal yaralanmaların yerlerini doğrulamak için her beyin hasarı grubundan iki sıçan sakrifiye edildi. Kallus oluşumu, kallus/diyafiz oranları ve serum alkalen fosfataz (ALP) düzeyleri bir, üç ve altıncı haftalarda ölçüldü.

Bulgular: Kontrol, MK ve SK gruplarında kallus kitlelerindeki artışlar bir ve üç hafta arasında istatistiksel olarak anlamlı şekilde farklı idi $(\mathrm{p}<0.05)$. MK ve SK gruplarındaki bu artış bir hafta sonunda kontrol grubuna göre anlamlı olsa da, MK ve SK grupları arasında istatistiksel olarak anlamlı farklılık bulunmadı $(\mathrm{p}>0.05)$. Kontrol, MK ve SK grupları arasında kallus/diyafiz oranı açısından sadece bir haftada MK grubu lehine istatistiksel olarak anlamlı farklılık vardı $(\mathrm{p}<0.05)$. Üç haftada serum ALP düzeylerindeki artış MK ve SK gruplarında kontrol grubuna göre istatistiksel olarak anlamlı şekilde farklı, MK grubunda SK grubuna göre anlamlı derecede yüksek idi $(\mathrm{p}<0.05)$.

Sonuç: Travmatik beyin yaralanması sonrası artmış kemik iyileşmesi ve MK'de hasar arasında muhtemel bir ilişki vardır. Motor korteks TBY'de kırık iyileşmesi üzerinde daha aktif rol oynamaktadır.

Anahtar sözcükler: Kemik iyileşmesi, motor korteks, somatosensöriyel korteks, travmatik beyin yaralanması. 
Fractures in patients with concomitant brain damage heal faster and larger calluses are produced compared to patients without brain damage which has been shown radiologically and clinically in the literature. ${ }^{[1,2]}$ This faster and larger callus formation pathophysiology is still unknown. All possible theories to uncover this phenomenon has been focused on brain.

Cortical functions of the brain are mainly divided into motor cortex (MC) and somatosensory cortex (SC). Determining which cortex plays an active role in traumatic brain injury (TBI) cases will be the first step in explaining the unknown cause of the increase in fracture healing. The $\mathrm{MC}$ is the portion of cortex that provides the spinal cord with input that determines much of an organism's motor actions. ${ }^{[3]}$ Motor cortex receives direct and indirect inputs from multiple cortical areas, including premotor, executive, and sensory centers and, as a result, its output is thought to be determined by both internally- and sensorydriven factors. The SC is the portion of cortex that provides the spinal cord with input that determines much of an organism's sensorial actions. ${ }^{[3]}$ Input from the primary SC to $\mathrm{MC}$ has long been speculated to contribute to sensorimotor integration and to be a major determinant of MC's output. ${ }^{[4]}$

The effect of TBI in patients with concomitant long-bone fractures has long been discussed. In the 1960s, Calandriello ${ }^{[5]}$ was the first to describe radiographically exuberant bone formation in patients with severe TBI and concomitant fractures. None of the investigations provided definitive evidence as to whether this interaction leads to quicker bone healing, increased callus formation, or a certain type of heterotopic ossification. It remains unclear whether the above described phenomenon represents physiological bone healing in terms of "physiological restoration of bone tissue, structure and function after injury" or is a side effect of other central or peripheral signaling cascades known to involve bone morphogenetic pathways. ${ }^{[6,7]}$ It has not been clearly identified yet whether this pathway belongs to the MC or SC. In this study, we aimed to investigate whether the MC or SC is more active in the course of bone healing after TBI.

\section{MATERIALS AND METHODS}

This study was conducted at Başkent University Medical Faculty between June 2014 and August 2014. The project, numbered DA 14/07, was approved by the decision of the Başkent University Medical and Health Sciences Research Board and Animal Experiments Ethics Committee on 24/03/2014 (numbered 14/14) and supported by the Başkent University Research Fund. This experimental study was carried out in accordance with the principles of Declaration of Helsinki and the Guide for the Care Use of Laboratory Animals.

The number of Wistar albino rats used was determined by power analysis. Thirty-three adult male Wistar albino rats (age, 8 to 10 months; weighing, 250 to $300 \mathrm{~g}$ ) were chosen because of the neuroprotective effect of progesterone hormone and periosteal thickness in childhood. ${ }^{[8]}$ The rats were housed under conditions of controlled temperature $\left(20 \pm 2^{\circ} \mathrm{C}\right)$ in standardized cages with a 12-hour light/ darkness cycle and ad libitum access to food and water. Prior to inclusion in the study, the animals were kept on the laboratory premises for at least one week in order to minimize stress. All surgical (a)

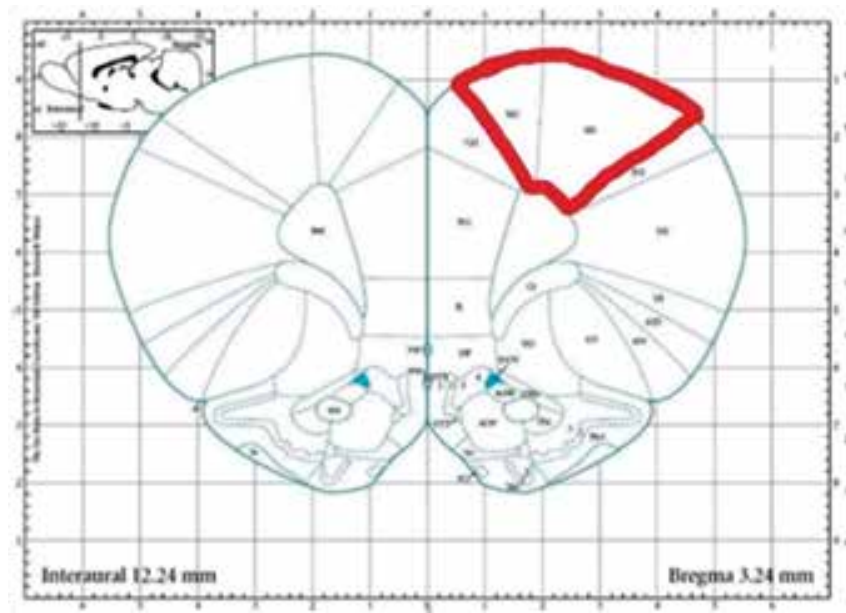

(b)

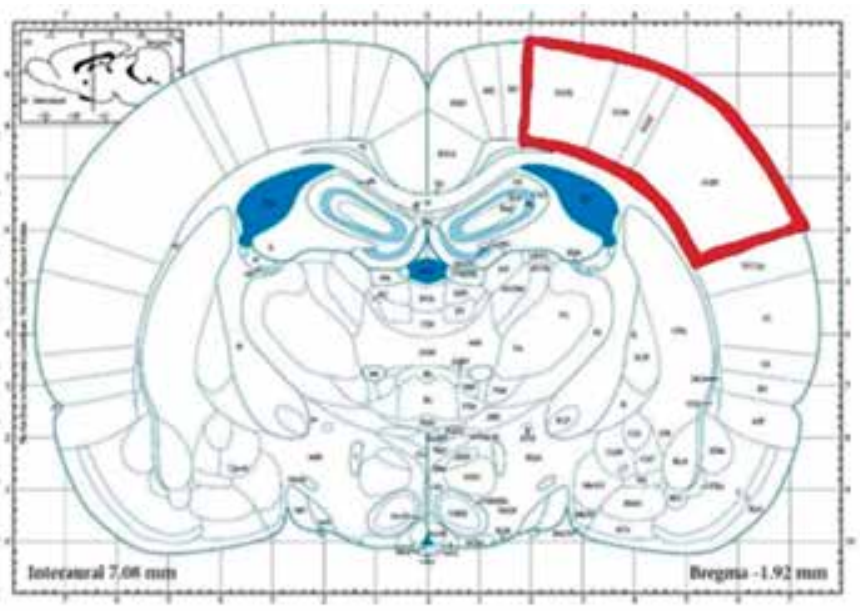

Figure 1. Schematic view of motor and somatosensory cortexes in a rat brain. ${ }^{[8]}$ (a) Motor cortex. (b) Somatosensory cortex. 
procedures were performed on a heating pad $\left(37^{\circ} \mathrm{C}\right)$ in spontaneously breathing animals anesthetized with $6-8 \mathrm{mg} / \mathrm{kg}$ xylazine (Rompun $2 \%$ solution, $50 \mathrm{~mL}$ vial, Bayer-Türk İlaç Ltd., İstanbul, Turkey) and $60-80 \mathrm{mg} / \mathrm{kg}$ ketamine (Ketalar $50 \mathrm{mg} / \mathrm{mL} 10 \mathrm{~mL}$ vial, Pfizer İlaçları Ltd., İstanbul, Turkey).

Since eight lobes and gyri in both hemispheres of the human brain are not encountered in rats, focal damage in the study was limited to the MC, which lies anterior to the bregma in the rat skull, and the SC, which lies posterior to the bregma (Figure 1). ${ }^{[8]}$

Because of the transverse courses of the neuroanatomical pathways, cortical damage was applied to the right hemispheres, while fractures were performed in the left femurs. The rats were divided into three groups as follows: femoral fracture without brain damage (control group: $n=11$ ), right MC damage with left femur fracture (MC group; $n=11$ ), and right SC damage with left femoral fracture (SC group; $\mathrm{n}=11$ ). The brain injuries and femoral fractures were performed in the same operation. To avoid bone scattering, $1 \mathrm{~mm}$ Kirschner wires (K-wires) were introduced into the femoral medullary canal before the creation of the fracture.

The skin over the left trochanter major was incised approximately $1 \mathrm{~cm}$. After the soft tissue was dissected, a $1 \mathrm{~mm}$ K-wire was introduced through the femoral medullary cavity from the trochanteric tip to the distal femoral cortex manually (Figure 2a). The wounds were closed with Ethilon 4-0 suture (Ethicon, Johnson \& Johnson, Norderstedt, Germany). To avoid soft tissue injuries and unforeseeable callus formation during the natural healing period, closed fractures were used. ${ }^{[9,10]}$ After the introduction of the $\mathrm{K}$-wires, closed transverse femoral shaft fractures were applied according to Bonnarens and Einhorn's blunt guillotine model, which was described in 1984, by dropping $1.1 \mathrm{~kg}$ from $15 \mathrm{~cm}$ and applied in several experimental fracture healing studies (Figure 2b). ${ }^{[1-14]}$ The pattern of the fracture and the location of the $\mathrm{K}$-wires were confirmed by X-rays (Figure 2c).

Brain trauma models are designed mostly to create diffuse brain damage. However, in Feeney's weight drop model, it is possible to create focal damage by dropping weight onto the dura mater, which is exposed by craniotomy. ${ }^{[15]}$ For this reason, Feeney's weight drop model was chosen.

To perform the craniotomy, the cranium was exposed after a mid-line scalp incision. For the MC group, the craniotomy was performed with a burr hole on the right anterolateral side of the bregma (Figure 2d). For the SC group, the craniotomy was performed on the right posterolateral side of the bregma (Figure 2e). Irrigation with saline solution was performed during the drilling to avoid thermal injury. Bipolar cauterization was used for the dural bleeding.

To create the focal cortical damage, a $20 \mathrm{~g}$ brass weight was dropped from $15 \mathrm{~cm}$ onto a $3.5-\mathrm{mm}$-wide Steinmann nail inserted through the burr hole according to Feeney's model (Figures $2 \mathrm{f}$ and $\mathrm{g}$ ). ${ }^{[16]}$

After the operations, the rats were monitored in the postoperative care unit without any food or movement restriction. In MC group, all rats showed spastic paralysis at front foot and circular movement pattern. In SC group, all rats were tested for whisker response, which showed that this reflex was diminished in
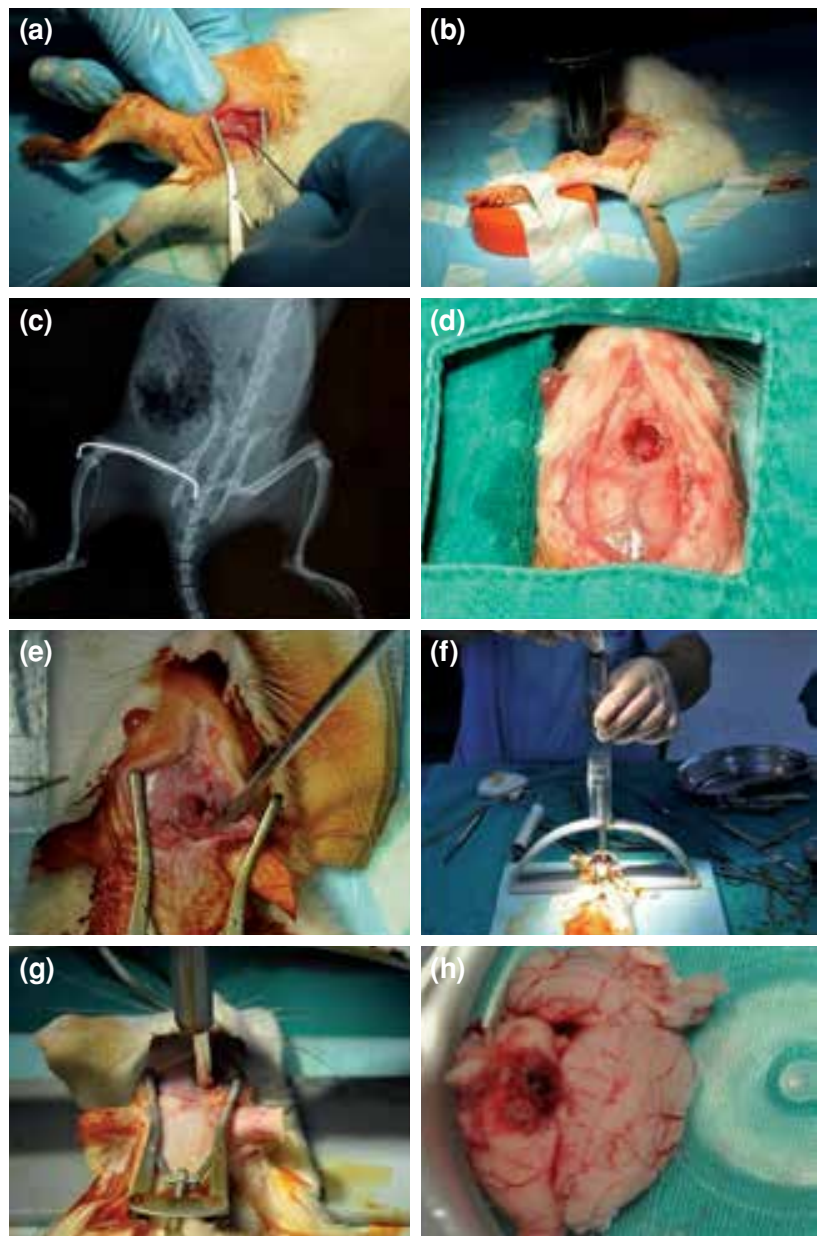

Figure 2. Stages of experimental design. (a) Femoral intramedullary fixation with Kirschner wire. (b) Closed fracture of femur with Bonnarens and Einhorn method. (c) Control X-ray of femoral fracture and fixation. (d) View of motor cortex after craniostomy with usage of burr. (e) View of somatosensorial cortex after craniostomy with usage of burr. (f, g) Mechanism of focal brain damage. (h) Macroscopic view of focal brain damage at pathological evaluation. 


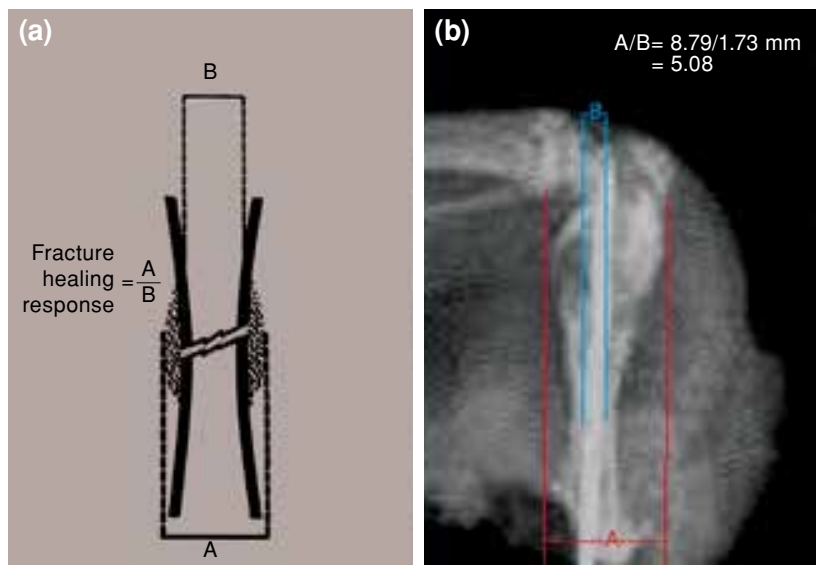

Figure 3. View of callus/diaphysis ratio measurement. ${ }^{[9]}$ (a) View of callus/diaphysis ratio measurement. (b) Third case in motor cortex group at sixth week.

all rats. On the second postoperative day, two rats each from the MC and SC groups were sacrificed to verify the extent of cortical brain damage by simple randomization and the rat brains were subjected to a pathological examination (Figure $2 \mathrm{~h}$ ).

At postoperative one, three, and six weeks, the callus/diaphysis ratio and volume of new callus formation at the femoral fracture site were measured on plain X-rays ${ }^{[17]}$ and evaluated by a blinded orthopedic surgeon (Figures 3 and 4).

Alkaline phosphatase (ALP) activity may serve as a marker of the course and rate of bone healing after sustained fractures. ${ }^{[18]}$ For this reason, blood ALP levels of the rats were measured simultaneously (ARCHITECT cSystem; Abbott Laboratories, Abbott Park, IL 60064, USA). ${ }^{[19]}$

All rats were sacrificed at week six postoperatively by delivering a high-dose thiopental (Pentothal, Abbott SpA, Aprilia LT, Italy) injection.

During the course of the study, four rats died in the control group; thus seven rats in the control group, nine rats in the MC group, and nine rats in the SC group remained alive during the six weeks.
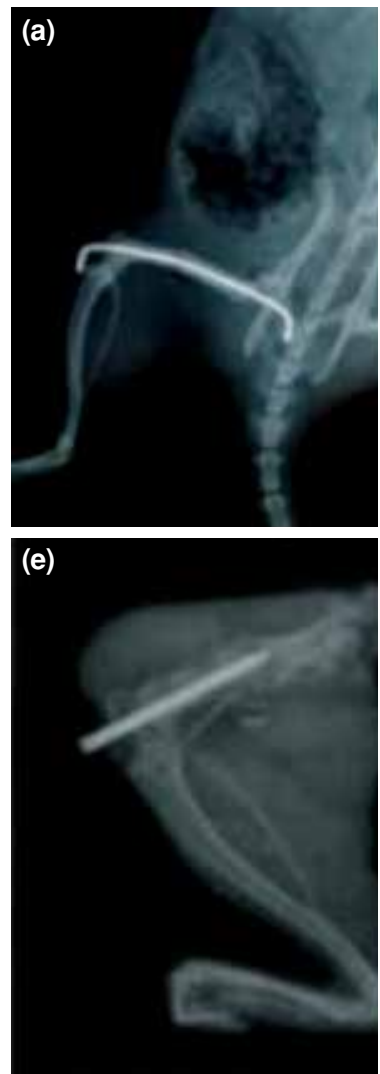
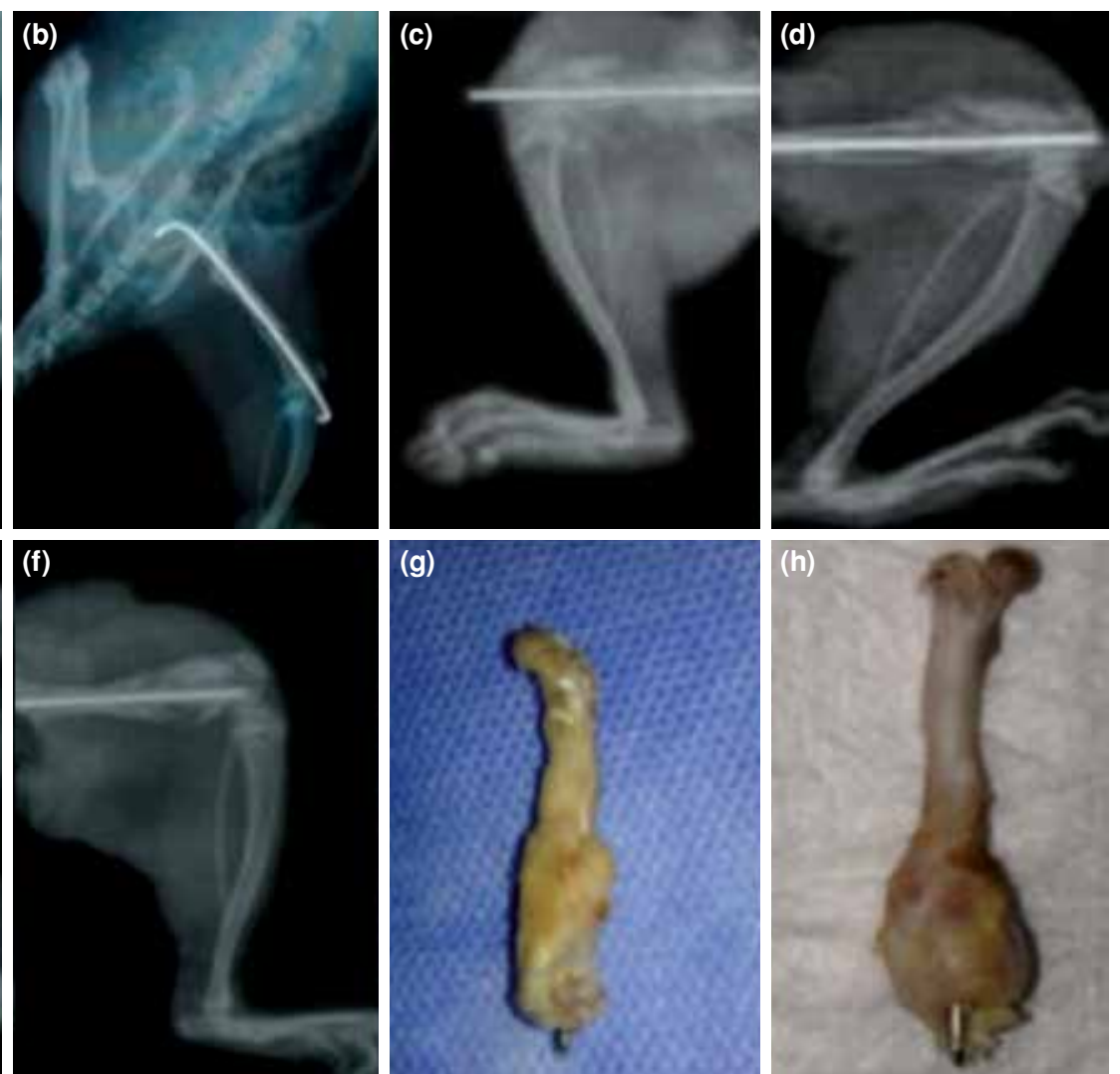

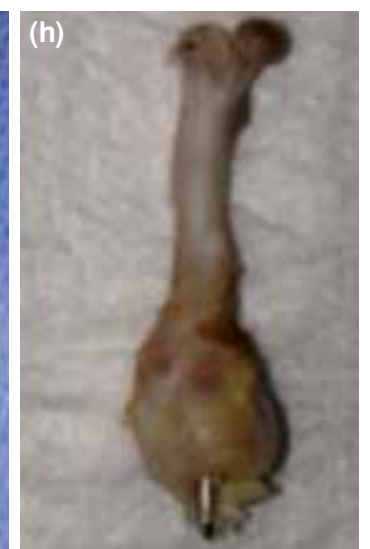

Figure 4. (a) Early postoperative X-ray for motor cortex group. (b) Early postoperative X-ray for somatosensory cortex group. (c) Postoperative third week X-ray for motor cortex group. (d) Postoperative third week X-ray for somatosensory cortex group. (e) Postoperative sixth week X-ray for motor cortex group. (f) Postoperative sixth week X-ray for somatosensory cortex group. $(\mathbf{g}, \mathbf{h})$ Femurs from motor cortex and somatosensory cortex groups after sacrification. 


\section{Statistical analysis}

The PASW version 17.0 was used to analyze the data set (SPSS Inc., Chicago, IL, USA). Since the assumptions of parametric tests were met, one-way analysis of variance (ANOVA) was used to compare the means of the three independent groups in one measurement; on the other hand, repeated measures ANOVA was used to compare the means of the three groups at three different times. The results of the statistical analysis were expressed as mean value \pm standard deviation, median value, minimum and maximum values, and interquartile range. Values of $p<0.05$ were regarded as statistically significant.

\section{RESULTS}

The mean operation duration was 24 minutes (range, 18-36 minutes) in the control group, 52 minutes (range, 38-79 minutes) in the MC group, and 44 minutes (range, 32-69 minutes) in the SC group.

The callus/diaphysis ratio, volume of the callus tissue, and serum ALP levels, which are the most commonly used indicators of fracture union in radiological and biochemical follow-ups, were measured (Table I).

The increase in callus masses in the control, MC, and SC groups was significantly different between weeks one and three $(p<0.05)$. Although this increase in the MC and SC groups was significantly different compared to that in the control group at the end of week one, no significant difference was found between the MC and SC groups ( $p>0.05)$. Similarly, the increase in callus masses at the end of week three was significantly different between the SC and control groups and between the MC and SC groups $(\mathrm{p}<0.05)$. Time distributions (postoperative weeks one, three, and six) of the increase in callus masses among the groups are shown in Figure 5. Only week one callus/diaphysis ratios were significantly different among the control, MC, and SC groups $(\mathrm{p}<0.05)$. No significant difference was found at three or six weeks between the three groups $(\mathrm{p}>0.05)$.

Although callus/diaphysis ratios were higher in the MC group than in the control group $(\mathrm{p}<0.05)$, there was no significant difference between the control and SC groups or between the MC and SC groups.

The distribution of change in callus/diaphysis ratio among the groups according to the time of radiological examinations (postoperative weeks one, three, and six) is given in Figure 6.

Serum ALP levels were significantly different between the control, MC, and SC groups at one,

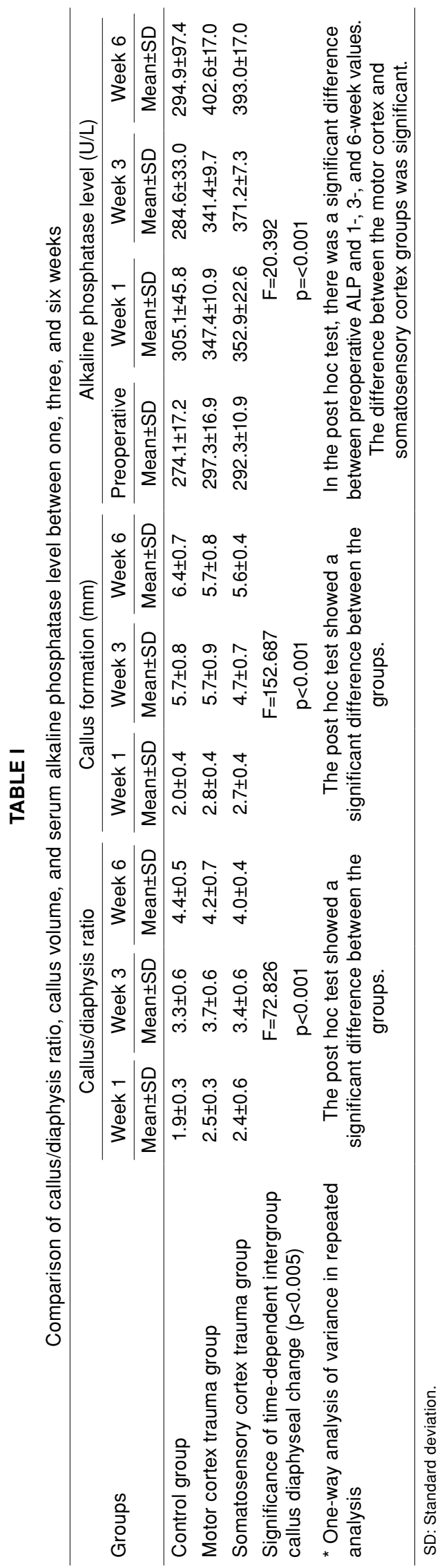




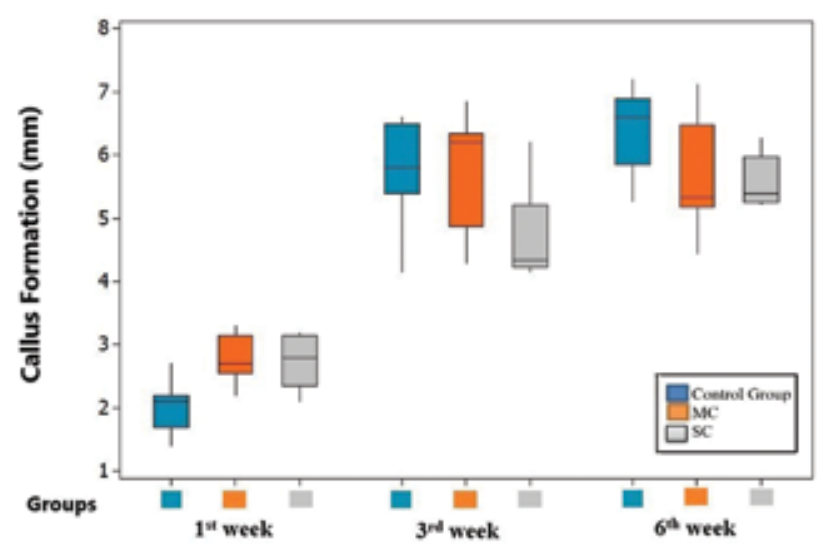

Figure 5. Callus formation distribution according to weeks. MC: Motor cortex; SC: Somatosensory cortex.

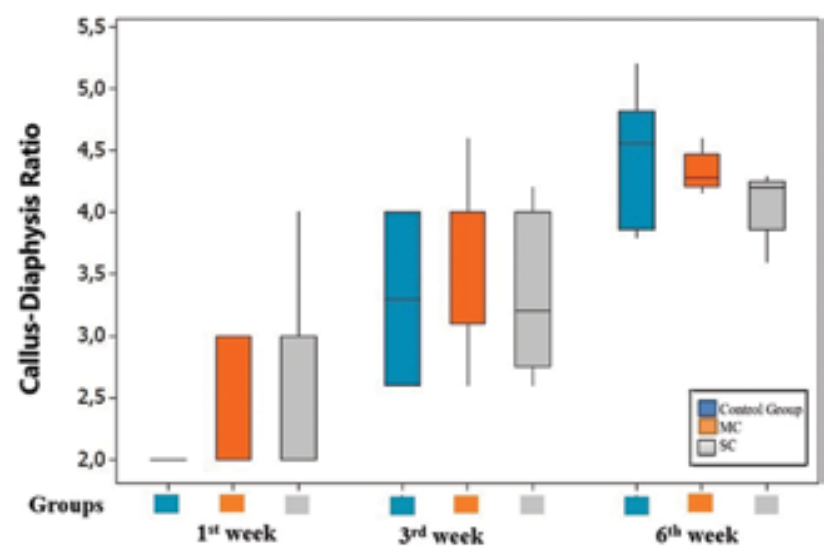

Figure 6. Callus/diaphysis ratio distribution according to weeks. MC: Motor cortex; SC: Somatosensory cortex.

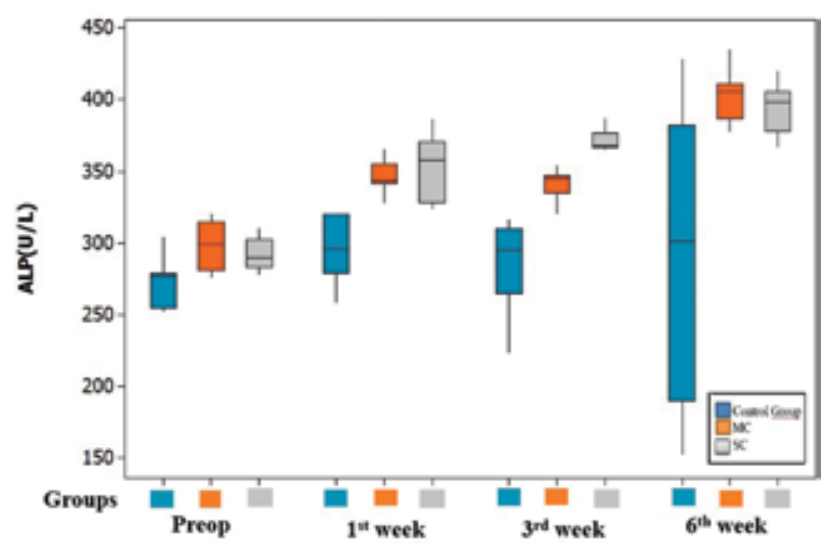

Figure 7. Alkaline phosphatase (U/L) levels distribution according to weeks.

ALP: Alkaline phosphatase; MC: Motor cortex; SC: Somatosensory cortex. three, and six weeks $(\mathrm{p}<0.05)$. Although the increase in serum ALP levels at one week was significantly different in the MC and SC groups compared to the control group, there was no significant difference between the MC and SC groups ( $>0.05)$. The increase in serum ALP levels at three weeks was significantly different in the MC and SC groups compared to the control group and significantly different in the $\mathrm{MC}$ group compared to the SC group ( $\mathrm{p}<0.05)$.

While the increase in serum ALP levels at six weeks was significantly different in the MC and SC groups compared to the control group $(\mathrm{p}<0.05)$, no significant difference was found between the $\mathrm{MC}$ and SC groups $(p>0.05)$. The distribution of change in serum ALP levels among the groups according to time (postoperative weeks one, three, and six) is given in Figure 7.

In the variance analysis based on the time variable, the callus/diaphysis ratio and diaphysis callus formation volume among all groups were significantly different. There was a significant difference between all groups in terms of preoperative ALP and one- and six-week ALP values, whereas there was a significant difference between ALP values according to time only between the MC and SC groups $(\mathrm{p}<0.05)$ (Table I).

\section{DISCUSSION}

The most important finding of this experimental study was that fracture healing was the fastest in those with isolated MC damage. This situation revealed that the parameters used in the follow-up of fracture healing were insignificant after the early period.

Most of the studies in the literature are focused on the hormones and mediators that are secreted after TBI and these studies could not define a specific brain region that is responsible for this phenomenon. We did not encounter any study in the literature that defines the influences of motor or somatosensory cortices on fracture healing in patients with concomitant TBI. Formation of new bone and fracture healing are processes comprising complicated mechanisms involving local growth factors, systemic mediators, and cytokine-mediated actions. Fracture healing is a proliferative physiological process to facilitate the repair of a fracture. ${ }^{[20]}$

The fracture healing response in patients with concomitant TBI has been radiologically shown to be higher than in patients without brain damage in a clinical report of 53 cases by Spencer ${ }^{[17]}$ In patients with head injury, they reported a $73 \%$ increase in callus volume and a marked increase in the fracture healing rate compared to the control group. 
Callus volumes in the TBI groups were also higher compared to the control group in our study. However, in the MC damaged group, callus volume was higher compared to the SC damaged group, and this volume was at its highest level at three weeks.

Giannoudis et al. ${ }^{[2]}$ demonstrated that while the mean fracture union time of the brain damage patients was almost half of that of the patients without brain damage, callus/diaphysis ratios were apparently different. Similar results were obtained in our study. Callus/diaphysis ratios were higher in the brain damage groups compared to the control group. However, during the course of fracture healing, the early callus/diaphysis ratio was higher in the MC damaged group. Newman et al. ${ }^{[22]}$ suggested the "alkalotic environment hypothesis" with the idea that most patients who suffer brain damage are intubated and hyperventilated and so their blood $\mathrm{pH}$ might be alkalotic. In their study, the mean blood $\mathrm{pH}$ value of the patients was 7.49 and they stated that this alkalotic $\mathrm{pH}$ might enhance callus formation by precipitating calcium ions. In our study, the volume of the callus increased in the time-dependent distribution of fracture union as time passed.

In our study, we started with the hypothesis that there is a possible relationship between enhanced fracture healing after TBI and brain MC or SC injuries. To date, the methods used to monitor the bone healing process have been based on assessment by the patient and radiographic findings. Since the patient's opinion is highly subjective, the radiographic findings depend on the radiologist's experience, and since the monitoring of bone healing is a long-lasting process, measurements of biochemical parameters appear to be the only objective evidence of changes occurring during bone regeneration.

Muljacić et al. ${ }^{[18]}$ reported that the increase in ALP correlated with the increase of S-bone ALP levels. In addition, changes in ALP levels on days seven and 14 as compared to those on day one postinjury were associated with changes in S-bone ALP levels on the same day. Likewise, the callus volume correlated with the decrease, no change, or increase in the levels of ALP and S-bone ALP in the same way. Based on these results, it may be concluded that monitoring changes in the biochemical parameters ALP and bone-specific ALP allows early detection of fracture healing rates. A minor increase in the activity or no change in the level of the biochemical parameters ALP and S-bone ALP in the first two weeks indicates successful fracture fixation, rapid bone healing, and the formation of minimal or insignificant callus. ${ }^{[18]}$ In our study, it was also found that serum ALP levels can be used as a biochemical parameter during the survey of fracture healing. However, the increase in ALP levels in TBI was higher compared to the no TBI group.

There are some limitations of this study. First, the callus size of the fracture sites could not be evaluated with micro computed tomography analyses. Secondly, the study sample size was small and also experimental repetition could not be performed. Thirdly, standard fractures might be maintained by using open fracture model in rats. Lastly, biomechanical evaluation should be investigated in a separate experimental research.

In conclusion, enhanced fracture healing with concomitant TBI was possibly related to the damage to the MC. Isolated MC injury is the type of TBI where fracture healing is most rapid. Future studies are required to elucidate the mechanisms behind this phenomenon and improve our understanding of the effect of TBI on bone regeneration.

\section{Declaration of conflicting interests}

The authors declared no conflicts of interest with respect to the authorship and/or publication of this article.

\section{Funding}

The authors received no financial support for the research and/or authorship of this article.

\section{REFERENCES}

1. Perkins R, Skirving AP. Callus formation and the rate of healing of femoral fractures in patients with head injuries. J Bone Joint Surg [Br] 1987;69:521-4.

2. Bidner SM, Rubins IM, Desjardins JV, Zukor DJ, Goltzman D. Evidence for a humoral mechanism for enhanced osteogenesis after head injury. J Bone Joint Surg [Am] 1990;72:1144-9.

3. Petrof I, Viaene AN, Sherman SM. Properties of the primary somatosensory cortex projection to the primary motor cortex in the mouse. J Neurophysiol. 2015;113:2400-7.

4. Hiraba H, Yamaguchi Y, Satoh H, Ishibashi Y, Iwamura Y. Deficits of masticatory movements caused by lesions in the orofacial somatosensory cortex of the awake cat. Somatosens Mot Res 2000;17:361-72.

5. Calandriello B. Callus formation in severe brain injuries. Bull Hosp Joint Dis 1964;25:170-5.

6. Morley J, Marsh S, Drakoulakis E, Pape HC, Giannoudis PV. Does traumatic brain injury result in accelerated fracture healing? Injury 2005;36:363-8.

7. Einhorn TA. The science of fracture healing. J Orthop Trauma 2005;19:S4-6.

8. Wei J, Xiao GM. The neuroprotective effects of progesterone on traumatic brain injury: current status and future prospects. Acta Pharmacol Sin 2013;34:1485-90.

9. Paxinos G, Charles W, editors. The Rat Brain in Stereotaxic Coordinates. The New Coronal Set. 5th ed. New York: Elsevier; 2004.

10. Buckwalter JA, Einhorn TA, Marsh JL. Bone and joint healing. In: Bucholz Rw, Heckman Jd, editors.Rockwood 
and Green's Fractures in Adults. Vol 1. 5th ed. Philadelphia: Lippincott, Williams and Wilkins; 2001. p. 245-271.

11. Bonnarens F, Einhorn TA. Production of a standard closed fracture in laboratory animal bone. J Orthop Res 1984;2:97-101.

12. Koçkara N, Sofu H, Issin A, Çetinkaya M, Tayfur M, Süleyman B. Pregabalin does not affect fracture healing adversely. Eklem Hastalik Cerrahisi 2017;28:19-24.

13. Halıcı M, Öner M, Güney A, Canöz Ö, Narin F, Halıcı C. Melatonin promotes fracture healing in the rat model. Eklem Hastalik Cerrahisi 2010;21:172-7.

14. Toğral G, Arıkan M, Korkusuz P, Hesar RH, Ekşioğlu MF. Positive effect of tadalafil, a phosphodiesterase- 5 inhibitor, on fracture healing in rat femur. Eklem Hastalik Cerrahisi 2015;26:137-44.

15. Xiong Y, Mahmood A, Chopp M. Animal models of traumatic brain injury. Nat Rev Neurosci 2013;14:128-42.

16. Allen GV, Gerami D, Esser MJ. Conditioning effects of repetitive mild neurotrauma on motor function in an animal model of focal brain injury. Neuroscience 2000;99:93-105.

17. Spencer RF. The effect of head injury on fracture healing. A quantitative assessment. J Bone Joint Surg [Br] 1987;69:525-8.

18. Muljacić A, Poljak-Guberina R, Zivković O, Bilić V, Guberina M, Crvenković D. Course and rate of postfracture bone healing in correlation with bone-specific alkaline phosphatase and bone callus formation. Coll Antropol 2013;37:1275-83.

19. Nakajima A, Shimoji N, Shiomi K, Shimizu S, Moriya H, Einhorn TA, et al. Mechanisms for the enhancement of fracture healing in rats treated with intermittent low-dose human parathyroid hormone (1-34). J Bone Miner Res 2002;17:2038-47.

20. Trentz OA, Handschin AE, Bestmann L, Hoerstrup SP, Trentz OL, Platz A. Influence of brain injury on early posttraumatic bone metabolism. Crit Care Med 2005;33:399-406.

21. Giannoudis PV, Mushtaq S, Harwood P, Kambhampati S, Dimoutsos M, Stavrou Z, et al. Accelerated bone healing and excessive callus formation in patients with femoral fracture and head injury. Injury 2006;37:18-24.

22. Newman RJ, Stone MH, Mukherjee SK. Accelerated fracture union in association with severe head injury. Injury 1987;18:241-6. 